\title{
CORRECTION
}

\section{Correction to: NMR structure of the HIV-1 reverse transcriptase thumb subdomain}

\author{
Naima G. Sharaf ${ }^{1} \cdot$ Andrew E. Brereton $^{2} \cdot$ In-Ja L. Byeon ${ }^{1} \cdot$ P. Andrew Karplus ${ }^{2} \cdot$ Angela M. Gronenborn ${ }^{1}$
}

Published online: 12 December 2017

๑) Springer Science+Business Media B.V., part of Springer Nature 2017

\section{Correction to: J Biomol NMR (2016) 66:273-280 https://doi.org/10.1007/s10858-016-0077-2}

In the original publication of the article, the given name and family name of the author P. Andrew Karplus was published incorrectly. The name should read as "P. Andrew" - Given name and "Karplus" - Family name.

1 Department of Structural Biology and Pittsburgh Center for HIV Protein Interactions, University of Pittsburgh, School of Medicine, Biomedical Science Tower 3, 3501 Fifth Avenue, Pittsburgh, PA 15260, USA

2 Department of Biochemistry and Biophysics, $2011 \mathrm{Ag} \&$ Life Sciences Bldg, Oregon State University, Corvallis, OR 97331, USA 